\title{
CHARAKTERYSTYKA CHIŃSKIEGO PRAWA CYWILNEGO - WYBRANE ASPEKTY
}

\section{Chiński system prawny - ujęcie historyczne ${ }^{1}$}

Chińska kultura prawna wzorowała się na etyce konfucjańskiej, przyjmując od czasów dynastii Qin ostatecznie rozwiązania synkretyczne - konfucjańsko-legistyczne. Bezpośrednim tego przejawem było skoordynowanie norm etycznych $l i$ wraz z normami prawnymi fa, które odtąd miały względem siebie charakter komplementarny. Od początku kształtowania się systemu prawnego w Państwie Środka przyjęto model prawa kontynentalnego, w którym istotną rolę odgrywały kodyfikacje prawne, zwłaszcza w zakresie prawa karnego i administracyjnego. Inaczej kształtowała się sytuacja na gruncie prawa prywatnego, gdzie wszelkie spory były rozstrzygane za pomoca mediacji i koncyliacji, co z jednej strony miało podkreślać pokojowe usposobienie samych Chińczyków, z drugiej zaś przyczynić się do rozwiązania problemu wewnątrz grupy².

W schyłkowym okresie panowania dynastii Qing (1902 r.) została powołana przez rząd specjalna komisja kodyfikacyjna (falü bianzuanguan 法律编纂管), która miała za zadanie dokonać rewizji dotychczas obowiązujących przepisów, biorąc za punkt wyjścia swoich rozważań rozwiązania przyjęte w zachodnich systemach prawnych. Przewodniczącymi komisji byli Shen Jiaben i Wu Tingfang. Proces reformy miał charakter raczej pozorny z uwagi na to, że tworzone regulacje miały przede wszystkim podkreślać obowiązek wykazywania się lojalnością wobec panujących w Państwie Środka władz. Pomimo dość restrykcyjnych wytycznych komisji kodyfikacyjnej udało się zakończyć swoje prace sukcesem, czego zwieńczeniem było przekształcenie dotychczasowego feudalnego kodeksu dynastii Qing w nowoczesny kodeks karny. Oprócz tego został również opracowany projekt kodeksu cywilnego. Warto podkreślić, że był on wzorowany na modelu niemieckim. Recepcja taka

1 Wcześniejsze rozważania na ten temat: zob. M. Łagiewska, Etyka sędziowska w Chinach-teoria i praktyka [w:] Nowa posycja Chin w zmieniajacym sie śmiecie. Polityka - ekonomia - spoteczeństwo, red. J. Marszałek-Kawa, A. Stelmach, M. Walkowski, Toruń 2017, s. 185-187.

2 R. Tokarczyk, Kultura prawna konfucjanizmu [w:] Chiny w oczach Polaków. Ksiega jubileuszowa z. okazji 60-lecia nawiqzania stosunków dyplomatycznych międyy Polska a Chinska Republika Ludowa, red. J. Włodarski, K. Zeidler, M. Burdelski, Gdańsk 2010, s. 502-505. 
była możliwa za pośrednictwem Japonii. Twierdzenie to potwierdza struktura nowo opracowanego aktu prawodawczego, która odzwierciedla założenia niemieckiego Bürgerliches Gesetzbuch (BGB). Chiński kodeks cywilny składał się zatem z pięciu ksiag, takich jak: przepisy ogólne, prawo zobowiązań, rzeczowe, rodzinne i spadkowe. Co więcej, przygotowany projekt, wzorując się na rozwiązaniach niemieckich, dokonywał także wyraźnego rozgraniczenia pomiędzy prawem cywilnym a handlowym, które dotychczas nie było spotykane w Państwie Środka³.

Wraz z wybuchem rewolucji Xinhai pod przywództwem Sun Yat-sena (Sun Zhongshana) do abdykacji został zmuszony Pu Yi - ostatni z cesarzy panującej dynastii Qing. Rozpoczęły się wówczas czasy Republiki Chińskiej. Nowa sytuacja polityczna nie stanowiła rozwiązania dotychczasowych problemów ani pod względem narodowym, ani społecznym. W państwie panował bowiem chaos związany z obecnością licznych ośrodków władzy. W przeciwieństwie do dotychczasowych rozwiązań ich legitymizacja do rządzenia nie wynikała z tzw. mandatu Nieba. Decydująca rolę odgrywała zatem siła wojskowa. Biorąc pod uwagę rozwój prawa zarówno w schyłkowym okresie panowania dynastii Qing, jak i na początku Republiki Chińskiej, warto podkreślić, że specjalnie powołane komisje naukowe były wysyłane do różnych krajów (m.in. USA, Japonii, jak również do państw europejskich) celem zaznajomienia się z przyjętymi tam rozwiązaniami prawnymi.

Konsekwencją takich działań było powstanie w 1907 r. w strukturze Ministerstwa Sprawiedliwości komisji odpowiedzialnej za przeprowadzenie nowej kompilacji zarówno prawa karnego, jak i cywilnego. Pracom wspomnianej jednostki przewodniczył Shen Qiapen, który miał wiedzę nie tylko w zakresie chińskiej tradycji prawa, lecz jednocześnie wykazywał się znajomościa prawa zachodniego ${ }^{4}$. Wspomnianej recepcji podlegały zwłaszcza normy europejskiego prawa kontynentalnego, o czym świadczy ponowne wzorowanie chińskiego kodeksu cywilnego przez rząd Kuomintangu na rozwiązaniach zaczerpniętych wprost z niemieckiego BGB z 1896 r. Warto jednak pamiętać, że sami Niemcy nie zdawali sobie z tego sprawy, gdyż ustawodawca chiński odwoływał się wprost do kodyfikacji japońskich, opracowanych w epoce Meiji (1868-1912), które z kolei wzorowały się na prawie niemieckim. Na uwagę zasługuje fakt, że prawo japońskie było wówczas spisane za pomoca tradycyjnych znaków chińskich, co w konsekwencji stanowiło podstawę dla dalszych prac legislacyjnych i kodyfikacyjnych w Państwie Środka. Można zatem mówić o recepcji prawa europejskiego w Chinach, która nie miała jednakże charakteru bezpośredniego. W 1929 r. uchwalono chiński kodeks cywilny, obok którego warto wyróżnić wiele ustaw szczegółowych, takich jak prawo ubezpieczeń, akcyjne czy bankowe. Należały

3 Chen Lei, The Historical Development of the Civil Law Tradition in China: A Private Law Perspective, „The Legal History Review” 2010, no. 78, s. 163-164.

4 A. Kość, Recepcja prawa europejskiego w czasie Republiki Chińskiej (1912-1949) [w:] Chiny w oczach Polaków..., s. 515-517. 
one do tzw. prawa handlowego (shangfa 商法), które występowało obok prawa cywilnego (minfa 民法). Wspólnie natomiast w literaturze przedmiotu prawo cywilne i handlowe określane były terminem sprawy cywilne (minshi 民事). Wzorując się również na rozwiązaniach japońskich, w Chinach przyjęto tzw. sześć ustaw, wśród których należy wyróżnić konstytucję, kodeks cywilny i administracyjny z 1929 r., a także postępowania cywilnego, karny, postępowania karnego z 1935 r. ${ }^{5}$

Inaczej kształtowała się sytuacja, gdy władzę przejął Mao Zedong. Z dniem 1 października 1949 r. została proklamowana Chińska Republika Ludowa. Nastapiło wtedy uchylenie obowiązujących dotychczas aktów prawodawczych, tzw. sześciu ustaw Kuomintangu, gdyż nie odzwierciedlały one założeń marksizmu-leninizmu. Tym samym podjęto decyzję o uformowaniu całego systemu prawnego od nowa. Podstawa przyjmowanych rozwiązań prawnych do 1957 r. był model radziecki ${ }^{6}$. Znalazło to swój wyraz zarówno w przepisach prawa rodzinnego, jak i Konstytucji ChRL z 1954 r. W dalszej kolejności teoria marksizmu-leninizmu uległa w Chinach istotnym modyfikacjom, przekształcając się ostatecznie w maoizm. Na lata 1957-1976 przypadł okres nihilizmu prawnego (falï xumuzhuyi 法律虚无主义), co przejawiało się zarówno likwidacją w 1959 r. działającego w państwie Ministerstwa Sprawiedliwości, jak i zerwaniem dotychczasowych stosunków z zagraniczną nauką prawa (nie tylko radziecka, ale też zachodnia). Negatywny wpływ na funkcjonowanie całego systemu prawnego wywarła rewolucja kulturalna, która rozpoczęła się w 1966 r. W tym okresie nie były uchwalane nowe akty prawodawcze, a dotychczas działające instytucje prawne przestały spełniać swoją funkcję - nastapił okres wyniszczenia grupy prawników, bibliotek i zgromadzonej w nich literatury prawniczej ${ }^{7}$. Sytuacja zaczęła się zmieniać od 1978 r., gdy rozpoczął się proces otwierania się Chin na świat (gaige kaifang 改革开放). To wówczas z inicjatywy Deng Xiaopinga został również przyjęły program określany mianem Czterech Modernizacji, którego celem było stworzenie (socjalistycznego) systemu prawnego z chińską specyfiką. Można go było wyrazić w czterech fundamentalnych zasadach, takich jak: obowiązywanie (you fa ke yi 有法可依), przestrzeganie (you fa bi yi 有法必依), ścisłe egzekwowanie (zbi fa bi yan 执法必严), ściganie naruszeń prawa (wei fa bi jü 违法必究) ${ }^{8}$.

Ibidem, s. 519-520.

6 V. Behr, Development of a New Legal System in the People's Republic of China, „Louisiana Law Review" 2007, vol. 67, no. 4, s. 1163; por. K. Zweigert, H. Kötz, An Introduction to Comparative Law, Amsterdam 1977, s. 293-295; V.H. Li, The Legal System of the People's Republic of China and Problems of Equity [w:] Equity in the World's Legal Systems: A Comparative Study, ed. R.A. Newman, Brussels 1973, s. 519-538.

7 M. Stępień, Chinskea kultura prawna [w:] Leksykon socjologii prawa, red. A. Kociołek-Pęksa, M. Stępień, Warszawa 2013, s. 32.

8 M. Stępień, M. Zajęcki, Podstawy aksjologiczne ržadów (przę) prawa w Chińskiej Republice Ludowej po 1978 roku [w:] Azjatyckie strategie polityki miedsynarodowej i regionalnej, red. J. Marszalek-Kawa, S. Gardocki, Toruń 2013, s. 103. 
Mówiąc o motywach wprowadzenia nowych rozwiązań prawnych po 1978 r., warto wskazać, że nadrzędnym celem było utrzymanie w państwie stabilizacji. Władze zdały sobie sprawę z konieczności przeciwdziałania chaosowi oraz z potrzeby utrzymania stabilności zwłaszcza w okresie następującym po rewolucji kulturalnej w Chinach. Uznały tym samym, że będzie to możliwe za pomoca prawa. Wyraziły zatem swój sprzeciw wobec negatywnych skutków, które wynikały z prowadzenia polityki zgodnie z wolą jednego tylko decydenta. Znaczyło to również najpierw zbudowanie systemu prawnego, który miał poprzedzać modernizację kraju. Oba te czynniki miały jednocześnie stanowić podstawę legitymizacji rządów sprawowanych jednopartyjnie przez Komunistyczną Partię Chin?.

\section{Akty prawodawcze regulujące prawo cywilne}

Wraz z proklamowaniem Chińskiej Republiki Ludowej podjęto decyzję o zrezygnowaniu z tradycyjnego podejścia, zgodnie z którym w kodeksie cywilnym znajduja się regulacje dotyczące prawa rodzinnego (adopcyjnego) i spadkowego. W Chinach komunistycznych uznano natomiast, że wspomnianą materię mają regulować szczegółowe ustawy ${ }^{10}$. Ze względu na ograniczoną objętość niniejszego artykułu przedstawiam wybrane akty prawodawcze odnoszące się do problematyki prawa cywilnego, w szczególności prawa małżeńskiego i instytucji własności.

Podstawowym aktem prawodawczym regulujacym sferę prawa cywilnego są tzw. ogólne zasady prawa cywilnego Chińskiej Republiki Ludowej z dnia 12 kwietnia 1986 r., które obowiązywały od 1 stycznia 1987 r. ${ }^{11}$ Akt ten składał się ze 156 artykułów skomplikowanych w 9 rozdziałach i dotyczył m.in. takich kwestii, jak osoby fizyczne, zdolność prawna i zdolność do czynności prawnych, opieka, uznanie za zmarłego, przedsiębiorcy. Po części zawierał przepisy tożsame z tymi, które znajdują się w części ogólnej polskiego kodeksu cywilnego. Był natomiast uzupełniony regulacjami, które w sposób ogólny i możliwie jak najszerszy dotyczyły problematyki prawa cywilnego. Nie należy go jednakże utożsamiać z kodeksem cywilnym. Aktualnie trwaja prace legislacyjne w tym zakresie, które mają zostać zakończone do 2020 r.

Podejmując próbę charakterystyki prawa małżeńskiego w Chinach, należy pamiętać, że w Azji Wschodniej zasadą było zawieranie małżeństw aranżowanych, co leżało w gestii rodziny. Powszechne były sytuacje, gdy sami małżonkowie poznawali się w dniu zaślubin. Kobiety zaś były zobowiązane przede wszystkim do

9 Ibidem, s. 105-106.

${ }_{10}$ Yi Jiming, A Historical Perspective on the Unification of Private Law and the Future of the Civil Code, „Social Sciences in China” 2015, vol. 36, no. 3, s. 76.

11 Ogólne zasady prawa cywilnego z dnia 12 kwietnia 1986 r. ze zm. (中华人民共和国民法 通则: 2009年修正), www.npc.gov.cn. 
okazywania swojemu mężowi posłuszeństwa ${ }^{12}$. Wiek XX charakteryzował się zmianami o charakterze społecznym, które wpłynęły w istotny sposób na postrzeganie ich pozycji oraz na nowo określiły ich rolę w społeczeństwie chińskim. Dotyczyły one nie tylko płaszczyzny socjologicznej, lecz również znalazły swoje odzwierciedlenie w reformie systemu prawnego. W czasach Republiki Chińskiej (1912-1949) kobietom zostały przyznane liczne prawa. Wśród najważniejszych z nich należy wymienić m.in. prawo do edukacji oraz prawo do pracy. Kobiety cieszyły się tym samym bardziej niezależną pozycją niż dotychczas. Trend taki utrzymał się również w czasach proklamowania ChRL. Świadczy o tym nowo uchwalone w 1950 r. prawo małżeńskie, które przyznawało kobiecie prawo wyboru swojego przyszłego małżonka oraz możliwość wniesienia sprawy o rozwód (art. 1, 17). Zmiany te w pozytywny sposób oddziaływały na postrzeganie pozycji kobiety. Odtąd powszechne było zawieranie związków monogamicznych oraz równy status prawny małżonków (art. 1) ${ }^{13}$. Zasady te zostały również potwierdzone w kolejnej ustawie - prawie małżeńskim z 1980 r. Z chwilą wprowadzenia tego aktu prawodawczego ustalono minimalny wiek uprawniający do wstąpienia w związek małżeński na 22 lata w przypadku mężczyzn oraz 20 lat dla kobiet. Tym samym został on podniesiony o 2 lata w porównaniu z dotychczasowymi rozwiązaniami wynikającymi z art. 4 prawa małżeńskiego z 1950 r. U przyczyn wdrożenia nowych rozwiązań leżała chęć lepszego wypełnienia założeń płynących z polityki jednego dziecka. Zostały tym samym stworzone podstawy prawne nakładające na obywateli obowiązek zawarcia związku małżeńskiego w późniejszym wieku ${ }^{14}$.

Wskazując regulacje dotyczace prawa własności, należy podkreślić, że zostały zawarte w Konstytucji ChRL z 1982 r., ogólnych zasadach prawa cywilnego z 1986 r., jak również w ustawie o prawach rzeczowych z dnia 16 marca 2007 r. Wstępny projekt nowych regulacji został przygotowany wspólnie przez szkołę prawa działającą na Uniwersytecie Ludowym w Pekinie (Renmin Daxue 人民大学) oraz Chińską Akademię Nauk Społecznych. Znalazł on następnie swoje odzwierciedlenie w uchwalonej ustawie. Został tym samym stworzony system ochrony praw własności z chińską specyfiką. Wspomniana ustawa dokonuje wyraźnego rozróżnienia takich pojęć, jak posiadanie i własność, zapewniając im tym samym inne środki ochrony prawnej ${ }^{15}$. Należy

12 K. Gawlikowski, Zapiski zpawilonu odlatujacego żurawia, „Azja-Pacyfik” 2000, nr 3, s. 308, 309.

13 Prawo małżeńskie Chińskiej Republiki Ludowej z dnia 13 kwietnia 1950 r. (中华人民共和 国婚姻法), www.npc.gov.cn.

14 Xia Yan Ruth, Wang Haiping, Do Anh, Qin Shen, Family Policy Policy in China: A Snapshot of 1950-2010 [w:] Handbook of Family Policies Across the Globe, ed. M. Robila, New York 2014, s. 259; Prawo małżeńskie Chińskiej Republiki Ludowej z dnia 10 września 1980 r. (中华人民共和国婚 姻法), www.npc.gov.cn.

15 Wang Liming, Zhou Youjun, Progressing with the Reform and Opening up: retrospective of China's Civil Law (1978-2008), „Frontiers of Law in China” 2009, no. 5, s. 175-176. 
jednocześnie pamiętać, że wzoruje się ona na rozwiązaniach charakterystycznych dla modelu prawa kontynentalnego, w szczególności zaś niemieckiego i szwajcarskiego ${ }^{16}$.

Mówiąc o rodzajach własności występujących w Państwie Środka, należy podkreślić, że w Konstytucji ChRL z 1982 r. w pierwszej kolejności znajduje się odniesienie do tzw. socjalistycznej własności publicznej (shehuiz̧̧uyi de gonggongcaichan 社会主义的公共财产). Zgodnie z treścia art. 12 jest ona nie tylko święta, lecz również nienaruszalna (shensheng buke qinfan 神圣不可侵犯) ${ }^{17}$. W chińskim systemie prawnym występuje ponadto tzw. własność kolektywów (jiti suoyou 集体 所有), co zostało uregulowane w art. 9-10 Konstytucji ChRL. Innowacyjnym rozwiązaniem, wynikającym z nowelizacji konstytucji w 2004 r., było także objęcie ochrona „legalnej własności prywatnej” (befa de siyou caichan 合法的私有财产), która odtąd jest nienaruszalna (art. 13 Konstytucji ChRL). Mając na uwadze powyższe rozważania, można wskazać hierarchię własności obowiązującą w Chinach. Największa ochrona w myśl art. 10 Konstytucji ChRL przewidziana jest dla własności państwowej (guojia suoyou 国家所有), w dalszej kolejności - własności kolektywnej, najsłabszą pozycje zajmuje natomiast własność prywatna. Warto jednocześnie wskazać, komu przysługuja poszczególne rodzaje własności: państwowa należy do całego ludu (quanmin 全民), kolektywna jest tworzona przez tzw. masy pracujące danej wsi czy też regionu (jiti 集体), prywatna należy do obywateli, czyli gongmin (公民).

Porównując rozwiązania przyjęte $\mathrm{w}$ prawie polskim (art. 140 ustawy z dnia 23 kwietnia 1964 r. - Kodeks cywilny, Dz. U. Nr 16, poz. 93, ze zm.) i chińskim, należy podkreślić, że chiński prawodawca wprost uznał prawo własności za prawo do posiadania, używania i pobierania pożytków, jak również rozporządzania rzecza. Zrezygnował tym samym ze zwrotu „o korzystaniu z rzeczy”. Wskazał ponadto, w jaki sposób właściciel może reagować w przypadku naruszenia przysługującego mu prawa własności. Tak więc może on nie tylko zawrzeć ugodę (hejie 和解), lecz również przystapić do mediacji (tiaojie 调解), arbitrażu (zhongcai 仲裁), by dopiero w drodze ostateczności, gdy wyżej wymienione metody okażą się bezskuteczne, wnieść sprawę na drogę postępowania sądowego (susong 诉讼) - art. 32 prawa rzeczowego ${ }^{18}$.

16 Chen Lei, The Historical Development..., s. 160.

17 Konstytucja Chińskiej Republiki Ludowej z dnia 4 grudnia 1982 r. - dalej: Konstytucja ChRL [中华人民共和国宪法(2004修正)], www.npc.gov.cn.

18 P. Kozanecka, Chinska terminologia prawna z zakresu prawa wtasności, „Comparative Legilinguistics" 2016, nr 25, s. 7-2; ustawa Chińskiej Republiki Ludowej o prawach rzeczowych z dnia 16 marca 2007 r. (中华人民共和国物权法), www.npc.gov.cn; M. Wójciuk, Nowe prawo wlasności w Chińskiej Republice Ludowej [w:] Chiny w oczach Polaków..., s. 555-563; W. Jakóbiec, J. Rowiński, System konstytucyjny Cbinskiej Republiki Ludowej, Warszawa 2006, s. 40; por. też: M.D. Kielsgard, Lei Chen, The Emergence of Private Property Law in China and Its Impact on Human Rights, "Asian-Pacific Law \& Policy Journal” 2013, vol. 15, issue 1, s. 94-134; Wong Vince, Land Policy Reform in China: 


\section{Pierwsza księga kodeksu cywilnego ChRL - wybrane aspekty}

Krokiem w urzeczywistnieniu idei budowy „socjalistycznych rządów prawa z chińską specyfiką" było uchwalenie w dniu 15 marca 2017 r. przez Ogólnochińskie Zgromadzenie Przedstawicieli Ludowych (chiński parlament) pierwszej księgi nowo tworzonego kodeksu cywilnego. Mowa o ogólnych przepisach prawa cywilnego (dalej: OPPC; minfa zongze 民法总则 ${ }^{19}$, które uległy pewnym modyfikacjom $\mathrm{w}$ porównaniu $\mathrm{z}$ dotychczasowymi rozwiązaniami zawartymi w ogólnych zasadach prawa cywilnego (OZPC; minfa tongze 民法通则) z dnia 12 kwietnia 1986 r. Poniższe rozważania dotyczą stanu prawnego, który obowiązuje od 1 października 2017 r. Po pierwsze, w akcie tym wskazano, że jego celem jest uregulowanie stosunków osobistych i własnościowych pomiędzy osobami fizycznymi, prawnymi i jednostkami organizacyjnymi nieposiadającymi osobowości prawnej, uznając je za podmioty równorzędne (art. 2 OPPC). Podkreślono jednocześnie, że wszystkie strony stosunków cywilnoprawnych są sobie równe (art. 4 OPPC). Zmiana polega zatem na tym, że dotychczas OZPC regulowały stosunki, które zachodziły pomiędzy obywatelami, pomiędzy osobami prawnymi, jak również pomiędzy obywatelami a osobami prawnymi (art. 2 OZPC). Biorąc powyższe pod uwagę, należy podkreślić, że nastąpiło odejście od regulacji dotyczących jedynie obywateli na rzecz osoby fizycznej, co jest pojęciem szerszym, albowiem dotyczy każdego człowieka i nie wiąże się z jego obywatelstwem.

Kolejna modyfikacja wiaże się z zasadami, którymi powinny kierować się strony stosunków cywilnoprawnych. Zgodnie z nowymi przepisami, oprócz dotychczasowych zasad: sprawiedliwości, słuszności (gongping 公平), uczciwości i wiarygodności (chengshixinyong 诚实信用), a także dobrej wiary (chengxin 诚信), strony maja wypełniać swoje obowiązki oraz racjonalnie określać prawa i obowiązki każdej ze stron stosunku prawnego (art. 6-7 OPPC). Nie mogą one również dokonywać czynności prawnych prowadzących do naruszenia prawa czy porządku publicznego i dobrych obyczajów (gongxu liangsu 公序良俗), co wynika z treści art. 8 OPPC.

Nowym rozwiązaniem jest również przepis wskazujący, że strony stosunków cywilnoprawnych powinny podejmować działania, które miałyby na celu zarówno utrzymanie zasobów naturalnych, jak i ochronę ekologiczną środowiska (art. 9). Jest to innowacyjne rozwiązanie, zwłaszcza w kontekście problemów środowiskowych, z którymi boryka się aktualnie Państwo Środka.

Dotychczasowe przepisy wskazywały, że podejmowanie działań o charakterze cywilnoprawnym powinno odbywać się zgodnie z obowiązującymi przepisami,

Dealing with forced Expropriation and the Dual Land Tenure System, Centre for Comparative and Public Law, Hong Kong 2014, no. 25.

19 Ogólne przepisy prawa cywilnego z dnia 15 marca 2017 r. (中华人民共和国民法总则), www.npc.gov.cn. 
a w przypadku ich braku - na podstawie polityki państwowej (guojia zhengce 国家 政策). W myśl nowych regulacji w przypadku, gdy nie ma stosownych przepisów, istnieje możliwość odwołania się do zwyczaju, który nie pozostaje w sprzeczności z porządkiem publicznym i dobrymi obyczajami (art. 10 OPPC).

Kolejna różnica sprowadza się do zmiany przepisu, na którego podstawie obywatele (gongmin 公民) są równi pod względem zdolności prawnej - według nowych regulacji zasada egalitaryzmu odnosi się do wszystkich osób fizycznych (ziranren 自然人), co wynika z art. 14 OPPC. Dodano również w art. 15 przepis określający, co stanowi podstawę ustalenia terminu urodzenia i śmierci (mowa w tym przypadku odpowiednio o aktach urodzenia i zgonu). Gdyby określona osoba nie posiadała powyższych dokumentów, należy ustalić taki termin na podstawie wpisu w systemie rejestracji mieszkańców (buji dengji 户籍登记) bądź innych rejestrów, w których potwierdzona jest tożsamość danej osoby fizycznej (shenfen dengji 身份登记).

Innowacyjnym rozwiąaniem, niespotykanym dotychczas w chińskim ustawodawstwie jest przepis gwarantujący ochronę względem interesów dziecka jeszcze nienarodzonego (tai’er 胎儿). Domniemywa się wówczas, że ma ono zdolność prawna, na podstawie której może zarówno dziedziczyć (yichan jicheng 遗产继承), jak i przyjąć darowiznę (jieshou zengyu 接受赠与). Gdyby natomiast dziecko urodziło się martwe, należy wówczas przyjać, że jego prawa nigdy nie istniały (art. 16 OPPC).

Nowe regulacje dokonują jednocześnie rozróżnienia osób pełnoletnich i małoletnich. Zgodnie z przepisami osoby, które ukończyły 18. rok życia, są pełnoletnie, maja zatem pełną zdolność do czynności prawnych. W pozostałych przypadkach mamy do czynienia z osobami małoletnimi. Utrzymano natomiast w mocy dotychczasowe rozwiązanie, zgodnie z którym prawo przewiduje możliwość nabycia pełnej zdolności do czynności prawnych przez osobę, która ukończyła 16 lat i źródłem jej utrzymania jest jej własna praca (art. 18 OPPC).

Ważną zmianą w chińskim prawie cywilnym jest obniżenie wieku, w którym nabywa się ograniczoną zdolność do czynności prawnych. Dotychczas było to 10 lat, natomiast według nowych przepisów - 8 lat (art. 19 OPPC). Warto również w tym kontekście zwrócić uwagę, że w projekcie ogólnych przepisów prawa cywilnego proponowano, aby małoletni, którzy ukończyli 6. rok życia, mieli ograniczoną zdolność do czynności prawnych. Spotkało się to ze sprzeciwem ze strony nie tylko chińskich prawników, lecz również opinii publicznej, zgodnie bowiem uznano, że jest to zbyt radykalna zmiana. Rozgorzały tym samym dyskusje wokół postulowanych zmian i ich zasadności. Przeciwnicy wspomnianej reformy twierdzili, że sześcioletnie dziecko nie ma wystarczającej świadomości co do podejmowanych przez siebie decyzji. Z kolei zwolennicy takiej zmiany podkreślali, że w obecnych czasach małoletni są bardziej dojrzali pod względem rozwoju psychologicznego i częściej korzystają z różnego rodzaju aktywności społecznych, co uzasadnia, ich zdaniem, potrzebę obniżenia kryterium nabycia ograniczonej 
zdolności do czynności prawnych ${ }^{20}$. Ostatecznie w sprawie został osiagnięty konsensus - 8 lat, co spotkało się również z akceptacją dotychczasowych przeciwników reformy. Wiąże się to z tym, że w Chinach małoletni, którzy ukończyli 6 lat, są objęci obowiązkiem szkolnym. Na tej podstawie uznano, że po 2 latach nauki będą oni mieli rzeczywistą możliwość nabycia wiedzy z zakresu stosunków społecznych.

\section{Podsumowanie}

Mówiąc o chińskim prawie cywilnym, należy podkreślić, że początkowo w Państwie Środka priorytet przyznawano mediacjom i koncyliacjom. Od czasów Republiki Chińskiej przepisy prawa cywilnego były wzorowane na rozwiązaniach zachodnich, zwłaszcza niemieckim kodeksie BGB z 1896 r., co stało się możliwe za sprawą Japonii. Gdy została proklamowana Chińska Republika Ludowa, poprawiła się sytuacja kobiet, co potwierdzaja przepisy prawa małżeńskiego z 1950 i 1980 r., na mocy których odstapiono od możliwości zawierania małżeństw aranżowanych, przyznając kobietom jednocześnie prawo wyboru swojego przyszłego małżonka, jak również prawo wniesienia sprawy o rozwód.

Współcześnie w Chińskiej Republice Ludowej nie ma kodeksu cywilnego, niemniej jednak trwaja prace kodyfikacyjne w tym zakresie, które - zgodnie z zapowiedzą władz państwowych - maja zostać ukończone do 2020 r. Obowiązują natomiast ustawy szczegółowe, które dotyczą chociażby problematyki prawa małżeńskiego czy rzeczowego. Podstawowym aktem prawodawczym regulującym sferę prawa cywilnego były ogólne zasady prawa cywilnego z 1986 r., które na mocy decyzji Ogólnochińskiego Zgromadzenia Przedstawicieli Ludowych z 15 marca 2017 r. zostały zastąpione ogólnymi przepisami prawa cywilnego. Akt ten stanowi jednocześnie pierwszą księgę nowo tworzonego kodeksu cywilnego. Zawiera innowacyjne rozwiązania, dotychczas niespotykane w Państwie Środka, m.in. takie, jak możliwość dziedziczenia czy przekazania darowizny na rzecz dziecka jeszcze nienarodzonego. Symbolicznym krokiem naprzód jest jednocześnie odejście od dotychczasowej praktyki przyznawania określonych praw i obowiązków obywatelom na rzecz osób fizycznych.

${ }^{20}$ Li Shihong, Is it Right to Lower the Age of Limited Civil Conduct Capacity?, „Beijing Review” 2016, no. 30, http://www.bjreview.com/Nation/201607/t20160726_800063292.html (dostęp: 27.06.2017). 


\section{SUMMARY}

\section{CHARACTERISTICS OF THE CHINESE CIVIL LAW: SELECTED ASPECTS}

Chinese legal system changes dynamically. The conception of the "socialist rule of law with Chinese characteristics", introduced in 2014, confirms such theory. According to this idea, some legislative works in civil law were undertaken. The aim of the article is to present the historical aspects of this branch of law, its development in the Middle Kingdom and indicate as well the actual binding regulations of the civil law. The article seeks to provide an analysis of the general rules of the civil law which contains the first part of the new civil code. There are also mentioned some aspects of the marriage and property law in China. 